\title{
RESIKO DAN PERLINDUNGAN HUKUM BAGI PEKERJA ANAK BERDASARKAN UNDANG-UNDANG NO. 13 TAHUN 2003 TENTANG KETENAGAKERJAAN $J O$. UNDANG-UNDANG NO. 35 TAHUN 2014 TENTANG PERLINDUNGAN ANAK
}

\author{
Oleh \\ Sherly Ayuna Putri \\ Holyness N Singadimedja \\ Dosen pada Fakultas Hukum Universitas Padjadjaran
}

\begin{abstract}
Every child has the right to survival, growth and development and is entitled to protection from violence and discrimination as provided for in the 1945 Constitution of the State of the Republic of Indonesia. A child is a person who is not yet 18 years old, including a child who still in the womb. The legal issues raised in this study are: what is the risk for underage child labor according to positive laws in Indonesia?; and how children's rights and legal protections for child labor are based on Law no. 13 of 2003 on Manpower and Law no. 35 Year 2014 on Child Protection? This research is normative juridical research with analytical descriptive and qualitative descriptive research specification. This is a Library Research by using secondary data.

Some factors that can prevent children to work are: social institutions (custom rules in hereditary societies); weak business that is impossible to work in it or because of the high level of welfare; public view; Education related to the exam season, scholarships, school rules and working hours coinciding with school hours; and the attitude and prohibition of work from parents. Child labor reduction program and children's opinion are crucial to local potential as a resource of action and community's responsibility to participate. The program should involve all institutions related to the causal factors and carried out with good coordination because the problems of child labor and its emerging protection are interrelated and strengthen each other.
\end{abstract}

Keywords: manpower, child labor, legal protection, child's right.

\section{Pendahuluan}

Ketentuan Pasal 1 Ayat (1) dan (2) Undang-undang No.35 Tahun 2014 mengenai Perlindungan anak disebutkan bahwa:

1. Anak adalah seseorang yang belum berusia 18 (delapan belas) tahun, termasuk anak yang masih dalam kandungan.

2. Perlindungan Anak adalah segala kegiatan untuk menjamin dan melindungi Anak dan hakhaknya agar dapat hidup, tumbuh, berkembang, dan berpartisipasi secara optimal sesuai dengan harkat dan martabat kemanusiaan, serta mendapat perlindungan dari kekerasan dan diskriminasi.

Berkaitan dengan konsep perlindungan anak, secara khusus pada bidang ketenagakerjaan penanganan masalah pekerja anak di Indonesia hingga saat ini masih menghadapi tantangan berat terutama karena isu pekerja anak terkait dengan beberapa hal, baik yang langsung maupun tak langsung berpengaruh terhadap keberadaan pekerja anak. Faktor yang langsung berkaitan dengan pekerja anak adalah risiko atau bahaya yang timbul di lingkungan kerja, maupun dari jenis 
pekerjaan yang mereka lakukan. Sementara faktor yang tidak langsung mempengaruhi keberadaan pekerja anak adalah sistem maupun kondisi yang melingkupi anak, mulai dari ekonomi, sosialbudaya dan politik.

Di Indonesia sendiri masalah kemiskinan sudah sangat memprihatinkan. Masalah kemiskinan di negara berkembang seperti Indonesia selalu menjadi topik pembahasan yang sulit mencarikan jalan pemecahannya. Hal ini bisa di simpulkan dengan melihat jumlah masyarakat dengan tingkat ekonomi rendah yang semakin meningkat. Kemiskinan yang membuat masyarakat semakin terpuruk juga disebabkan oleh pembangunan yang tidak merata, yang semestinya ditujukan untuk kesejahteraan seluruh masyarakat. Kenyataan yang terjadi justru sebaliknya, yaitu masih banyaknya masyarakat yang tidak tersentuh dengan pembangunan dan sebagian masyarakat hanya menjadi korban dari pembangunan itu sendiri. Ini membuat masyarakat semakin tertindas dan terpuruk dalam kemiskinan. ${ }^{1}$

Pada hakekatnya anak tidak boleh bekerja karena waktu mereka selayaknya dimanfaatkan untuk belajar, bermain, bergembira, berada dalam suasana damai, mendapatkan kesempatan dan fasilitas untuk mencapai citacitanya sesuai dengan perkembangan fisik, psikologis, intelektual dan sosialnya. Namun pada kenyataannya banyak anak-anak dibawah usia 18 tahun yang telah terlibat aktif dalam kegiatan ekonomi dan menjadi pekerja anak antara lain di sektor industri dengan alasan tekanan ekonomi yang dialami orang tuanya ataupun faktor lainnya.

Dampak buruk yang timbul dari lingkungan maupun jenis kerja yang dilakukan anak tersebut tidak seluruhnya dapat dilihat pada saat ini juga, karena umumnya dampak tersebut baru terlihat setelah jangka waktu tertentu. Belum banyak studi yang dilakukan untuk mengukur seberapa jauh dampak maupun risiko akibat kerja yang dilakukan anak-anak.
Dalam penelitian ini, keluarga dan lingkungan tempat tinggal merupakan dua hal yang berpengaruh besar terhadap proses perkembangan psikologis anak, proses pemenuhan kebutuhan anak, dan turut mempengaruhi pilihan anak untuk bekerja. Pekerja anak yang memiliki kecenderungan bersikap destruktif (misal: pemarah, gemar membuat keonaran, gemar berjudi dan lain-lain) berada dalam keluarga dan lingkungan masyarakat yang memiliki perilaku destruktif pula, dan umumnya anak-anak tersebut bekerja di sektor berbahaya di wilayah itu. Sebagian besar keluarga pekerja anak ternyata tidak dapat berfungsi sebagai sarana untuk memenuhi kebutuhan jasmani anak (misal: kebutuhan makanan sehat, tempat tinggal layak, dan pakaian layak). Sebagian lainnya tidak dapat berfungsi sebagai tempat pemenuhan kebutuhan perkembangan psikologis anak (misal: tempat penanaman nilai atau norma positif, tempat pembentukan karakter diri yang positif).

Kemiskinan bukan satu-satunya penyebab seorang anak untuk bekerja, faktor lingkungan juga berperan sangat penting. Anak-anak yang hidup di lingkungan teman-teman yang cenderung menyukai bekerja daripada sekolah meskipun orang tua mereka cukup mampu untuk membiayai sekolah mereka. Sebab lingkungan teman-teman sebaya mempunyai pengaruh yang cukup besar dalam menanamkan nilai-nilai tertentu yang mereka anggap sesuai dengan dunia mereka. Jadi faktor kemiskinan bukanlah satu-satunya yang membuat anak untuk bekerja. Akan tetapi faktor kemiskinan menjadi faktor utama yang menyebabkan anakanak untuk bekerja.

Anak memutuskan bekerja karena faktorfaktor kemiskinan keluarga, hubungan antara keluarga yang tidak harmonis, pengaruh lingkungan, pengaruh teman sebaya dan orang dewasa, adanya penghargaan masyarakat yang tinggi terhadap anak yang bekerja dibandingkan anak yang tidak bekerja, dinamika perkembangan ekonomi masyarakat, adanya sumber daya lokal tertentu di 
suatu wilayah (misal: tambang marmer, laut, pertanian, dan lain-lain), pola rekrutmen yang mudah tanpa persyaratan rumit, kebutuhan akan tenaga kerja anak-anak, dan kemudahan akses terhadap informasi mengenai pekerjaan tertentu (misalnya: informasi pekerjaan di sektor garmen dan sektor tenaga kerja domestik di luar negeri), kebutuhan biaya pendidikan, sekolah yang dianggap tidak menarik bagi anak (sehingga anak kemudian memilih untuk bekerja daripada bersekolah), inisiatif anak sendiri, dan keinginan anak untuk mandiri.

Di lingkungan kerja, ditemukan bahwa mayoritas lingkungan kerja anak tergolong tidak layak bagi anak, dan beberapa di antaranya membahayakan. Sejumlah kecelakaan pernah dialami anak, yang berasal dari penggunaaan peralatan kerja yang membahayakan, tidak adanya alat perlindungan kerja, dan jenis pekerjaan yang berbahaya. Hampir semua partisipan pernah mengalami satu atau dua jenis kecelakaan kerja yang mengakibatkan luka, keracunan, bahkan risiko kematian. Selain kecelakaan, anak juga mengalami sejumlah eksploitasi berupa jam kerja yang panjang, upah minim, dan perlakuan kasar dari majikan dan orang dewasa. Rata-rata anak bekerja antara 4-10 jam sehari, dan rata-rata pernah mengalami pemotongan gaji atau penundaan pembayaran gaji. Ditemukan pula bahwa masalah ini jarang dianggap serius oleh masyarakat dan dipandang tidak lebih dari kejadian sehari-hari yang wajar bagi mereka.

Pekerja anak umumnya berasal dari keluarga miskin, relatif kurang memperoleh akses untuk mendapatkan pendidikan yang layak. Di beberapa lokasi penelitian, ditemukan bahwa pekerja anak bersekolah di sekolah yang tidak menyediakan sarana belajar yang memadai, tenaga pengajar dengan kualitas pendidikan rendah, dan tidak mendapatkan tunjangan pendidikan berupa beasiswa. Selain itu ditemukan pula lokasi sekolah yang sulit dijangkau anak dan adanya biaya-biaya tambahan yang membebani anak.
Kemiskinan bukan satu-satunya penyebab anak bekerja tetapi sebagai salah satu faktor pendorong anak bekerja. Antara satu faktor penyebab anak bekerja dengan faktor lainnya saling berkaitan bahkan saling memperkuat pada seorang anak. Hanya saja faktor yang dominan berbeda pada setiap pekerja anak. Faktor yang banyak muncul di area penelitian adalah keluarga dan inisiatifanak. Pola rekrutmen pekerja anak kebanyakan melalui jalur informal sesuai dengan jenis pekerjaan mereka. Proses yang dilalui hampir semuanya melalui teman, keluarga dan kerabat serta kenalan dekat. Sedang sebagian besar pekerjaan yang dimasuki tidak memerlukan persyaratan, kecuali di industri garmen, profesi penyanyi dan tukang pijat yang secara kasat mata tampak mempunyai keahlian khusus. Informasi yang diperoleh anak tentang pekerjaan tidak melalui media resmi tetapi melalui kenalan baik teman, tetangga, keluarga maupun saudara. Ada pula anak yang bertanya langsung ke pengusaha

Belum ditemukan adanya pengaruh masyarakat yang dapat dijadikan faktor pencegah anak bekerja. Faktor pencegah anak bekerja yang diungkapkan partisipan sifatnya hanya menunda anak untuk bekerja atau membuat anak berhenti bekerja sementara seperti sepi order, musim ulangan, hari-hari besar agama bahkan hal-hal seperti bantuan beras. Pemenuhan hak anak harus dipandang dalam perspektif pemenuhan hak individual bukan sebagai bentuk belas kasihan. Jika kita memandang hal itu dalam perspektif hak asasi maka pendekatan yang kita lakukan adalah dengan melibatkan setiap pihak termasuk anak itu sendiri. Pekerja anak umumnya mengalami kekurangan istirahat sehingga berpengaruh terhadap prestasi sekolah mereka. Pekerja anak juga kurang mendapatkan kesempatan untuk berekreasi, melakukan kegiatan ibadah, dan kegiatan belajar di rumah. Selain bekerja, anak ternyata juga mendapatkan beban pekerjaan rumah tangga. Anak perempuan cenderung mendapatkan 
beban pekerjaan rumah tangga lebih lama daripada anak laki-laki.

Pekerja anak pada umumnya harus mendapatkan perlindungan hukum sesuai dengan Undang-undang No. 13 Tahun 2003 tentang Ketenagakerjaan jo UU No.35 Tahun 2014 tentang Perlindungan Anak agar hak-hak dari pekerja anak terpenuhi. Strategi mengatasi permasalahan pekerja anak tersebut dapat terbagi menjadi dua besaran, yakni proses penyadaran, penyediaan program antara (intermediate program) guna menjembatani antara proses penyadaran dan penghapusan pekerja anak, serta proses eliminasi pekerja anak yang dimulai dari penghapusan sektor-sektor kerja terburuk.

Mengenai pekerja anak Undang-Undang Nomor 13 tahun 2003 tentang Ketenagakerjaan ini telah memberikan ketentuan larangan bagi siapapun untuk mempekerjakan atau melibatkan anak-anak dalam bentuk pekerjaan terburuk. Namun mengenai jenis-jenis pekerjaan yang dianggap "pekerjaan terburuk" tersebut tidak diatur lebih lanjut dalam suatu Undang-Undang melainkan ditetapkan melalui sebuah Keputusan Menteri Tenaga Kerja dan Transmigrasi Nomor 235/ MEN/2003 tentang jenis-jenis pekerjaan yang membahayakan kesehatan, keselamatan atau moral anak, yang mulai berlaku sejak tanggal 31 Oktober 2003. Pasal 3 dalam KEPMEN tersebut menetapkan usia 15 (lima belas) tahun atau lebih sebagai usia kerja anak, dan melarang anak usia dibawah 18 (delapan belas) tahun untuk melakukan pekerjaan yang berbahaya bagi kesehatan, keselamatan, atau moral mereka.

Undang-Undang ini juga hanya memberikan perlindungan hukum bagi pekerja/ buruh yang bekerja pada sektor formal dan hanya mewajibkan pengusaha atau pengguna jasa pekerja formal untuk mematuhi Undang-Undang mengenai perjanjian kerja, upah minimum, lembur, jam kerja, istirahat, dan hari libur. Sedangkan pekerja anak yang bekerja di luar hubungan kerja (sektor informal) tidak diatur dalam Undang-
Undang Nomor 13 Tahun 2003 Tentang Ketenagakerjaan, melainkan masih menggunakan ketentuan Undang-Undang Nomor 23 tahun 2002 Tentang Perlindungan Anak.

Pemerintah telah banyak mengeluarkan berbagai peraturan guna menciptakan ketertiban dan keamanan di masyarakat. Namun dalam implementasinya tidak semua peraturan tersebut dapat dilaksanakan dengan sebagaimana mestinya oleh para pelaksana undang-undang yang akibatnya dapat menimbulkan kerugian bagi pihak lain. Berkaitan di bidang ketenagakerjaan seharusnya pembangunan ketenagakerjaan dibangun sedemikian rupa sehingga terpenuhi hakhak dan perlindungan yang mendasar bagi pekerja/ buruh sehingga pada saat yang bersamaan dapat mewujudkan kondisi yang kondusif bagi pengembangan dunia usaha. Upaya penanggulangan terhadap pekerja anak dapat dilakukan secara terpadu antar sektor di pusat dan daerah.

Penanggulangan pekerja anak merupakan dilema pemerintah, di satu sisi pemerintah ingin melarang pekerja anak dan mengharapkan semua anak usia sekolah dapat mengembangkan intelektualitasnya di sekolah untuk mendapatkan Sumber Daya Manusia (SDM) yang bermutu di masa depan, sementara di sisi lain pemerintah pun tidak dapat menghindar dari kenyataan bahwa masih banyak keluarga miskin sehingga mengijinkan anak-anak yang terpaksa harus bekerja.

Berdasarkan latar belakang yang telah diuraikan di atas, pertanyaan yang menjadi fokus peneliti untuk dijawab adalah :

1. Bagaimana Risiko Bagi Pekerja Anak Dibawah Umur Menurut Hukum Positif di Indonesia?

2. Bagaimana Hak-hak Anak dan Perlindungan Hukum bagi Pekerja Anak Berdasarkan Undang-Undang Tentang Ketenagakerjaan dan Tentang Perlindungan Anak? 


\section{Metode Penelitian}

Metode penelitian merupakan salah satu unsur yang sangat dibutuhkan untuk mendapatkan hasil penelitian Dalam penulisan penelitian ini digunakan langkah-langkah sebagai berikut :

1. Metode pendekatan

Metode Pendekatan yang dipergunakan dalam penelitian ini adalah pendekatan yuridis normatif. Yuridis normatif yaitu penelitian dengan menerangkan ketentuan-ketentuan dalam peraturan Perundang-undangan yang berlaku.

\section{Spesifikasi Penelitian}

Spesifikasi Penelitian adalah deskriptifanalitis dan kualitatifdeskriptif. Deskriptif analitis yaitu dengan menggambarkan dan memberikan penjelasan atas suatu peristiwa yang sedang diteliti serta menganalisis berdasarkan data-data yang diperoleh dari hasil penelitian yang berdasarkan teori-teori dari ketentuanketentuan yang berlaku yang dapat memberikan penjelasan secara keseluruhan baik dari bidang hukum ketenagakerjaan dan perlindungan anak sehingga dapat diperoleh kesimpulankesimpulan dalam penulisan.

3. Tahap Penelitian

Penelitian ini lebih ditekankan kepada data kepustakaan (Library Research), yaitu penelitian yang dilakukan terhadap data-data sekunder. Hal ini dilakukan untuk mencari landasan teoritis juga hal-hal yang berhubungan dengan masalah-masalah yang dibahas dalam penelitian ini terdiri dari Undang-Undang Ketenagakerjaan dan Undang-Undang Perlindungan Anak.

Setelah peneliti mendapatkan kerangka pemikiran yang sesuai dengan karakteristik temuan-temuan penelitian, peneliti melakukan interpretasi dengan menghubungkan berbagai informasi yang didapat dalam proses penelitian menjadi rangkaian penjelasan yang sistematik. Sehingga, peneliti berharap dapat melakukan konfirmasi maupun kritik terhadap kerangka penelitian yang sudah ada sebelumnya dan mengembangkan bentuk-bentuk metodologi studi hukum dan kebijakan. Lebih jauh lagi, rangkaian penjelasan yang sistematik tersebut dapat menghasilkan rekomendasi yang dapat diterapkan dalam memperbaiki atau merubah situasi yang ada. Akhirnya, peneliti akan menarik benang merah dari serangkaian proses penelitian ini, berupa jawaban dari pertanyaan penelitian yang akan dituangkan dalam kesimpulan.

\section{Hasil dan Pembahasan}

\section{Resiko Pekerja anak dibawah umur menurut hukum positif}

Anak yang dibawah umur 18 (delapan belas) tahun tidak dapat dikatakan cakap hukum dan perbuatan yang dilakukannya belum mencapai kriteria perbuatan atau tindakan hukum. Dalam dunia kerja tentunya harus ada tindakan hukum yang dilakukan berupa perjanjian atau kontrak kerja.

Dalam hukum privat pengertian perjanjian dapat kita pahami bahwa: "Suatu perjanjian adalah suatu perbuatan dengan mana satu orang atau lebih mengikatkan dirinya terhadap satu orang lain atau lebih". Dari pengertian diatas dapat kita tarik benang merah bahwa dalam sebuah perjanjian melahirkan perbuatan atau lebih tepatnya perbuatan atau tindakan hukum dengan satu orang atau lebih karena perbuatan tersebut membawa akibat hukum bagi para pihak yang memperjanjikan dan selanjutnya mempunyai ikatan dengan satu orang atau lebih tersebut karena di dalam perjanjian terdapat unsur janji yang diberikan oleh pihak yang satu kepada pihak yang lain.

Dalam perjanjian ini orang terikat kepada akibat hukum yang muncul karena kehendaknya sendiri. Hal ini bila disandingkan dengan pekerja anak dibawah umur tentunya melanggar ketentuan yang ada karena dalam sebuah perjajijan ada 
syarat-syarat yang harus dipenuhi sebagamana tertera dalam Pasal 1320 KUHPerdata.

Dari pemaparan diatas sebuah konsep ideal dari sebuah aturan sudah cukup menjamin akan hak-hak anak dalam mengembangkan diri mereka, namun yang menjadi problema detik ini belum sepenuhnya terealisasi dan bahkan ironisnya pekerja anak belakangan ini memang sudah menjadi pemandangan yang lazim dilihat, dari perusahaan yang bergerak dibidang industri hingga warung-warung dan toko-toko kecil sekalipun.

Namun meskipun sudah ada UndangUndang yang mengatur tentang PerlindunganAnak, tetap saja pekerja anak berkeliaran dimana-mana. Dalam Undang-Undang itu dikatakan bahwa setiap anak memiliki hak untuk tumbuh dan berkembang sehingga orangtua dilarang menelantarkan anaknya. Jika terjadi pelanggaran maka akan dikenakan sanksi hukuman termasuk perusahaan yang mempekerjakan anak di bawah umur. Di sisi lain dalam Undang-Undang No.13 Tahun 2003 Tentang Ketenagakerjaan disebutkan bahwa anak-anak boleh dipekerjakan dengan syarat mendapat izin orang tua dan bekerja maksimum tiga jam seharinya. Namun kenyataannya penerapan semua UU itu tidak berjalan semestinya. Didalam Undang-Undang No.13 Tahun 2003 tentang Ketenagakerjaan kita dijelaskan bahwa pengusaha dilarang mempekerjakan anak dalam keadaan apapun dan dengan alasan apapun pengusaha tidak oleh mempekerjakan anak dibawah umur. Namun dalam upaya untuk memberikan pendidikan dan pelatihan pengusaha boleh mempekerjakan anak-anak dengan ketentuan yang berlaku sebagaimana dijelaskan dalam Pasal $68,69,70,71,72,73,74,75$ UU No.13 Tahun 2003 Tentang Ketenagakerjaan.

Dalam upaya-upaya pengembangan bakat sebagaimana dijelaskan dalam Undang-Undang diatas merupakan bentuk persiapan mental anakanak agar tidak kaget dalam menempuh dunia kerja kedepannya. Maksud yang perlu dipahami bahwa semua yang dapat dilakukan dalam konteks pengembangan diri mereka. Sebagian para orang tua beranggapan bahwa memberikan pekerjaan kepada anak-anak mereka merupakan proses belajar, belajar untuk menghargai pekerjaaan dan belajar untuk bertanggung jawab, mereka juga berharap anak-anak mereka dapat membantu meringankan beban mereka selaku orang tua. Selama masih dalam kondisi wajar dan sesuai dengan ketentuan UU kita hal tersebut sah-sah saja. Namun sebagian orang tua memberi pekerjaan yang diluar kemampuannya dan menghilangkan kesempatan kepada anak-anak untuk mengembangkan diri.

Keadaan seperti ini terkadang memberikan dampak yang cukup signifikan pada perkembangan psikologis anak dan mental yang dibangun. Tidak banyak keadaan seperti ini membuat anak menjadi brutal, terbelakang mental, krisis moral. Disadari ataupun tidak terdapat banyak ketentuan perundang-undangan yang mengatur perlindungan terhadap anak yang telah dilanggar oleh para pelaku, baik orang tua anak dan pengusaha yang telah mempekerjakan anak dibawah umur.

Akhirnya, disadari ataupun tidak terdapat banyak ketentuan perundang-undangan yang mengatur tentang resiko terhadap pekerja anak dan telah banyak aturan mengenai syarat-syarat sebagai pekerja anak dilanggar oleh para pelaku, baik orang tua anak maupun pengusaha yang telah mempekerjakan anak di bawah umur dengan praktek yang tidak selaras dengan kualifikasi yang dijabarkan sebelumnya menurut hukum yang berlaku di Indondesia. Status pelanggaran itu mengacu pada Pasal 68, Pasal 69 Ayat 1,Pasal 69 dan Ayat 2 Undang-Undang Republik Indonesia No.13 Tahun 2003 Tentang Tenaga Kerja. Termasuk juga pada Pasal 28J Ayat 1 UUD 1945

Posisi pemerintah dalam mensikapi masalah pekerja anak terlihat mendua; di satu sisi membuat larangan, tapi pada sisi lain memberi toleransi. Undang-Undang No. 23 Tahun 2002 
tentang Perlindungan Anak secara tegas melarang orang tua atau perusahaan mempekerjakan anak di bawah umur dan mengenakan sanksi hukuman kurungan yang cukup berat bagi pelanggar. Tetapi UndangUndang No.13 Tahun 2003 tentang Ketenagakerjaan membolehkan anak di bawah umur 18 tahun bekerja, asal dengan jam kerja tidak melebihi 3 jam/hari. Keputusan Menteri Dalam Negeri dan Otonomi Daerah No. 5 Tahun 2001 tentang Penanggulangan Pekerja Anak Pasal 1 menyatakan bahwa pekerja anak adalah yang melakukan semua jenis pekerjaan yang membahayakan kesehatan dan menghambat proses belajar serta tumbuh kembang. Ini berarti, anak yang melakukan pekerjaan yang tidak berbahaya tidak termasuk dalam definisi pekerja anak, dan karenanya (secara implisit) tidak dilarang. Pembatasan ini menjadi jelas jika dibaca ayat selanjutnya yang menyatakan bahwa Penanggulangan Pekerja Anak atau disebut PPA adalah suatu kegiatan yang dilaksanakan untuk menghapus, mengurangi dan melindungi pekerja anak berusia 15 tahun ke bawah agar terhindar dari pengaruh buruk pekerjaan berat dan berbahaya.

Secara konsepsional, setidaknya ada tiga pendekatan dalam memandang resiko sebagai pekerja anak dibawah umur, yang sekiranya dapat dipergunakan sebagai upaya untuk mengatasi dan sekaligus memberdayakan pekerja anak, yakni penghapusan (abolition), perlindungan (protection), dan penguatan atau pemberdayaan (empowerment)

Pendekatan penghapusan muncul berdasarkan asumsi bahwa seorang anak tidak boleh bekerja, karena dia harus sekolah dan bermain. Hal ini dilandasi oleh semangat dan kultur masyarakat industri maju Negara-negara Barat. Sebab dalam masyarakat yang sudah maturity industrinya, tidak ditemukan persoalan yang signifikan bahwa mereka para keluarga mengharuskan anaknya bekerja karena alasan ekonomi, sebagaimana negera-negara miskin di kawasan Asia,Amerika latin dan Afrika. Sehingga dalam Negara maju tersebut, sering kita jumpai aturan yang melarang segala jenis pekerja anak dan oleh karenanya praktek kerja anak harus dihapuskan.

Dunia anak adalah dunia sekolah dan dunia bermain, yang diarahkan kepada peningkatan dan akselerasi perkembangan jiwa, fisik, mental, moral dan sosial. Setting dan kurikulum sekolah anak di desain sedemikian rupa sehingga anak benar-benar "IN" dalam dunia mereka sendiri, yang merupakan bagian integral dari proses yang sistematis dalam melahirkan generasi serta dunia anak yang kondusif.

Pendekatan perlindungan, muncul berdasarkan pandangan bahwa anak sebagai individu mempunyai hak untuk bekerja. Oleh karenanya hak-haknya sebagai pekerja harus dijamin melalui peraturan ketenagakerjaan sebagaimana yang berlaku bagi pekerja dewasa, sehingga terhindar dari tindak penyalahgunaan dan eksploitasi.

Sedangkanpendekatan Empowerment, juga berangkat dari pengakuan terhadap hak-hak anak dan mendukung upaya penguatan pekerja anak agar mereka memahami dan mampu memperjuangkan hak-haknya. Dalam pandangan penulis pendekatan perlindungan dan pendekatan pemberdayaan inilah yang seharusnya menjadi dasar pijakan bagi Negara-negara di kawasan Asia, Amerika Latin dan Afrika, khususnya di Indonesia, lebih khusus lagi di daerah selaras dengan semangat dan esensi otonomi daerah.

\section{Hak-hak Anak dan Perlindungan Hukum bagi Pekerja Anak}

Dalam merespon begitu seriusnya permasalahan-permasalahan yang terjadi terkait pekerja anak, maka dibentuklah berbagai peraturan yang digunakan untuk melakukan perlindungan terhadap pekerja anak. Peraturanperaturan tersebut disamping ada yang merupakan 
upaya ratifikasi dari konvensi Internasional, juga sebagian merupakan peraturan yang dibuat atas dasar dan inisiatif pemerintah Indonesia. Secara khusus peraturan perundangan yang ada tersebut secara substansiil sudah cukup memadai, akan tetapi secara implementatif masih sangat jauh dari harapan.

Perlindungan terhadap pekerja anak salah satunya diatur dalam Undang-undang Nomor 20 Tahun 1999 tentang Ratifikasi ILO Convention No. 138 Concerning Minimum Age for Admission to Employment the Abolition of Forced Labour atau Konvensi ILO No. 138 Mengenai Usia Minimum Untuk Diperbolehkan Bekerja Tahun 1973. Indonesia telah meratifikasi konvensi ini melalui Undang-undang Nomor 20 Tahun 1999. Pada alenia keempat Konvensi menetapkan suatu naskah umum mengenai batasan umur yang secara berangsur-angsur akan menggantikan naskah-naskah yang ada yang berlaku pada sektor ekonomi yang terbatas. Hal ini karena sebelumnya memang sudah ada rumusan tentang batasan umur minimal untuk bekerja, hanya saja rumusan itu berbeda-beda untuk setiap jenis dan sektor kerja. Alenia keempat pembukaan ini juga menyebutkan bahwa tujuan dari konvensi ini sendiri adalah untuk menghapus anak sebagai pekerja pada kegiatan ekonomi secara keseluruhan.

Selanjutnya asas perlindungan, dalam Pasal 2 dirumuskan bahwa usia minimum untuk diperbolehkan bekerja adalah 15 tahun. Umur 15 tahun ini di adopsi dan usia sekolah wajib. Pasal 2 juga menyatakan bahwa tidak seorang pun yang berada di bawah usia wajib diperbolehkan bekerja atau masuk bekerja daiam suatu jabatan pada wilayah negara anggota ILO. Konvensi ini juga memuat larangan untuk bekerja pada alat angkutan yang ada pada wilayah negara tersebut. Pasal 3 konvensi merumuskan bahwa untuk jenis pekerjaan yang dapat membahayakan kesehatan, keselamatan, atau moral orang muda, batasan umur tidak boleh kurang dari 18 tahun. Pasal 3 juga merumuskan bahwa jenis-jenis pekerjaan yang berbahaya harus ditetapkan dengan peraturan perundang-undangan nasional.

Selain itu juga pada Undang-undang Nomor 1 Tahun 2000 tentang Ratifikasi ILO Convention No. 182 Concerning the Prohibition anil Intermediate Action for the Elimination of The Worst Forms of Child Labour Atau Konvensi ILO No. 182 Mengenai Pelarangan dan Tindakan Segala Penghapusan Bentuk-bentuk Pekerjaan Terburuk Pada Anak Tahun 1999. Rumusan instrumen internasional yang ditetapkan oleh ILO sebagai kelanjutan dari upaya perlindungan pekerja yang telah dirumuskan oleh konvensi sebelumnya adalah konvensi ILO No. 182. Konvensi ini lahir berdasarkan pertimbangan bahwa dipandang perlu adanya instrumen ketenagakerjaan yang baru untuk menghapus bentuk-bentuk pekerjaan terburuk bagi anak.

Beberapa muatan asas yang berkaitan dengan perlindungan anak terhadap eksploitasi anak sebagai pekerja dalam konvensi ini adalah asas perlindungan, asas pencegahan, asas penerapan secara efektif, dan asas kerjasama nasional. Konvensi ini juga memuat norma-norma yang berkaitan langsung dengan konsep perlindungan anak sebagai pekerja. Pasal 1 mewajibkan negara anggota untuk mengambil tindakan segera dan efektif untuk menjamin pelarangan dan penghapusan bentuk-bentuk terburuk kerja anak sebagai hal yang mendesak.

Pasal lain yang berkaitan dengan asas perlindungan anak sebagai pekerja adalah pasal 4, yang merumuskan bahwa untuk pekerjaan berbahaya harus diatur oleh peraturan atau undang-undang nasional, juga mensyaratkan bahwa negara-negara peserta wajib untuk melakukan identifikasi tempat-tempat adanya bentuk-bentuk pekerjaan terburuk tersebut berada Lebih lanjut pasal ini juga merumuskan adanya peninjauan berkala dan revisi tentang jenis-jenis pekerjaan terburuk tersebut Hal ini membuka peluang masuknya rumusan baru tentang jenis-jenis 
pekerjaan terburuk bagi anak. Untuk hal-hal yang berkaitan dengan penerapan secara efektif diatur dalam Pasal 5, Pasal 6 dan Pasal 7 konvensi ini. Pada prinsipnya konvensi ILO No. 182 mencoba memberikan rumusan perlindungan terhadap anak sehingga anak tidak dipekerjakan.

Undang-undang tentang perlindungan anak ini ditetapkan pada tahun 2002, dua belas tahun setelah Indonesia menyatakan meratifikasi konvensi hak anak dan sudah direvisi kembali pada tahun 2014. Dari lamanya rentang waktu ini terlihat kurang seriusnya pemerintah untuk benarbenar melakukan perlindungan terhadap hak-hak anak. Pasal 2 menyebutkan bahwa perlindungan anak bertujuan menjamin terpenuhinya hak-hak anak agar dapat hidup, tumbuh, berkembang, dan berpartisipasi secara optimal sesuai dengan harkat dan martabat kemanusiaan, serta mendapat perlindungan dari kekerasan dan diskriminasi, demi terwujudnya anak Indonesia yang berkualitas, berakhlak mulia, dan sejahtera, selanjutnya Pasal 20 mewajibkan kepada negara, pemerintah, masyarakat, keluarga dan orangtua untuk ikut bertanggung jawab terhadap perlindungan anak. Bagian lain dari undang-undang ini merumuskan ancaman pidana bagi pelaku eksploitasi anak, termasuk orang yang mengetahui adanya eksploitasi. Pasal-pasal dalam undang-undang ini sangat berkaitan dengan rumusan perlindungan anak sebagai pekerja. Terutama dengan kaitan jenis-jenis pekerjaan terburuk bagi anak seperti yang dimaksudkan dalam konvensi ILO No. 182. dengan adanya ketentuan pidana dalam undangundang ini, maka perlindungan terhadap anak terutama dalam hal anak sebagai pekerja, diharapkan dapat terlaksana. Undang-undang ini tidak mengatur secara khusus mengenai perlindungan anak sebagai pekerja. Akan tetapi ketentuan-ketentuan konvensi ILO No. 138 dan konvensi ILO No. 182 telah dijadikan dasar hukum adanya undang-undang ini.

Dilihat dari subtansi hukum positif, perspektif perlindungan pekerja anak memerlukan revisi mengingat banyaknya asumsi yang mengabsahkan pekerjaan bagi anak-anak sebagai bentuk dari proses edukasi di luar rumah (sektor publik) karena kemiskinan keluarga dan labour surplus. Kedua alasan itu sering menjadi justifikasi pemerintah untuk mempersilahkan pengusaha dan dunia kerja panjang (sehingga tidak bersekolah), beban yang berat dan di bawah tekanan yang tinggi.

Asumsi itu hanya menguntungkan dan memperkuat hegemoni pihak pengusaha, karena memperkenankan akumulasi keuntungan yang maksimal dengan mempekerjakan anak dibalik dalil kemiskinan dan labour surplus. Seharusnya pemerintah membalikkan asumsi itu dengan menggunakan sumber daya perusahaan dan dunia usaha yang pasti surplus dibandingkan pekerja anak yang miskin untuk membayar biaya dan ongkos yang harus dikeluarkan pemerintah untuk membiayai anak-anak yang bekerja. Sebagai kompensasinya, pengusaha bisa menggunakan keluangan waktu anak-anak untuk memberikan prestasi kerja dalam jangka yang tidak terlalu panjang. Hal ini merupakan kewajiban sosial politik kalangan industri dan dunia usaha terhadap negara dan pemerintah yang telah menyediakan kenyamanan berusaha dengan perolehan surplus ekonomi. Dengan demikian pekerja anak memperoleh upah dan jaminan kesejahteraan yang lebih proporsional, perlindungan yang terjamin karena jam kerja yang singkat dan bentuk atau jenis pekerjaan yang tidak menekan perkembangan fisik dan psikis anak-anak. Bekerja bagi anak tidak selalu memberi dampak yang buruk, sepanjang pekerjaan itu tidak merugikan perkembangan anak, bahkan dapat merupakan kesempatan bagi anak untuk mengembangakan kemampuan eksplorasi dan kreativitas serta menumbuhkan sikap gemar bekerja, disiplin dan mandiri.

Untuk memberikan perlindungan hukum terhadap pekerja anak, maka perlu mengambil 
pendekatan yang bersifat multi dimensional dan multi sektoral adalah:

1.Merubah persepsi masyarakat terhadap pekerja anak, bahwa anak yang bekerja dan terganggu tumbuh kembangnya dan tersita hak-haknya akan pendidikan tidak dapat dibenarkan.

2.Melakukan advokasi untuk secara bertahap mengeliminasi pekerja anak dengan perhatian pertama diberikan kepada jenis pekerjaan yang sangat membahayakan, dalam hal ini perlu ada kampanye besar-besaran untuk menghapuskan pekerjaan anak.

3.Mengundangkan dan melaksanakan peraturan perundang-undangan yang selaras dengan konvensi-konvensi internasional, khususnya Konvensi Hak Anak dan konvensi-konvesi ILO yang menyangkut anak

4.Mengupayakan perlindungan hukum dan penyediaan pelayanan yang memadai bagi anakanak yang bekerja disektor informal.

5.Memastikan agar anak-anak yang bekerja memperoleh pendidikan yang memadai yaitu minimal pendidikan dasar 9 tahun dan pendidikan ketrampilan melalui bentuk-bentuk pendidikan alternatif yang sesuai dengan kebutuhan mereka

Kendala yang dihadapi dalam menerapkan atau memberikan perlindungan terhadap anak yang bekerja adalah disebabkan karena pihak pekerja anak-anak itu sendiri banyak memanipulasi umur mereka yang tujuannya tidak lain agar mereka diterima bekerja. Pada umumnya jenis pekerjaan yang dimasuki anak beragam, seperti industri kerajinan rumah tangga, peternakan, pertanian, pabrik, pelayan toko, pelayan restoran, pembantu rumah tangga dan lain lain. Sisanya yang tidak bekerja, mereka masuk sektor informal, menjadi tukang semir sepatu, pedagang asongan dan tukang ngamen. Alasanalasan bekerja bermacam-macam, mayoritas disebabkan masalah ekonomi, sekolah putus dan membantu pendapatan keluarga. Alasan lain karena putus sekolah dan menganggap sekolah tidak dapat menjamin kelangsungan hidupnya apalagi sekolah membutuhkan dana.Pihak yang mempekerjakan anak yang melanggar ketentuan perundang-undangan dibidang ketenagakerjaan maka dapat dikenakan sanksi administratif sebagaimana diatur dalam Pasal 190 ayat (2) UU No.13 Tahun 2003 tentang Ketenagakerjaan yang menyatakan sanksi administratif dalam ayat (1) berupa:

a.Teguran

b.Peringatan tertulis

c.Pembatasan kegiatan usaha

d.Pembekuan kegiatan usaha

e.Pembatalan persetujuan

f.Pembatalan pendaftaran

g.Penghentian sementara sebagian atau seluruh alat produksi

h.Pencabutan izin

Pihak orang tua selalu juga mengungkapkan bahwa anak-anak dipekerjakan adalah untuk membantu meringankan pekerjaan orang tua, membantu menambah pendapatan keluarga, melatih anak agar bertanggung jawab dan masih banyak alasan lain karena biasanya mereka membayar pekerja anak dengan upah yang murah jika dibandingkan dengan pekerja dewasa. Pekerja anak juga lebih mudah diatur.

Kondisi kemiskinan yang disebut-sebut sebagai faktor utama yang menyebabkan anak terlantar yang memunculkan tenaga kerja anak. Di amping itu, ada faktor lain yang turut mendorong munculnya tenaga kerja anak, yaitu faktor kultur, lingkungan sosial-ekonomi keluarga, lemahnya perangkat hukum, pengawasan dan pelaksanaannya, permintaan (demand), penawaran (supply), menurunnya tingkat pendapatan pada sektor ekonomi di wilayah tertentu, serta relokasi industri.

Ketidakmampuan anak tersebut dalam kenyataannya ada yang dimanfaatkan oleh sebagian orang untuk melakukan pekerjaan yang tidak selayaknya harus dilakukan oleh anak seusianya, tetapi kenyataan tidak dapat dipungkiri, 
bahwa sebagian anak ternyata hidup memprihatinkan dan sampai sekarang ini problematika anak belum menarik banyak pihak untuk membelanya.

Penggunaan anak kecil sebagai pekerja sekarang ini dianggap oleh negara-negara kaya sebagai pelanggaran hak manusia, dan melarangnya, tetapi negara miskin mungkin masih mengizinkan karenakeluarga seringkali bergantung pada pekerjaan anaknya untuk bertahan hidup dan kadangkala merupakan satu-satunya sumber pendapatan.Mudahnya anak disuruh bekerja dengan upah murah dan kemiskinan menjadi faktor utama sehingga pekerja anak terus bertambah. Selain itu, mahalnya biaya pendidikan menyebabkan banyak anak terpaksa putus sekolah. Pandangan bersifat paternalistik yang menganggap keluarga yang mempekerjakan anak sebagai PRT sebagai jalan keluar bagi anak yang kurang mampu itu, juga menjadi salah satu faktor. Mempekerjakan anak di usia dini sangat memprihatinkan, apalagi bekerja di sektor informal karena pengeksploitasian terhadap anak akan cenderung terjadi.

\section{Kesimpulan}

1. Dalam resiko anak dibawah umur bekerja dan dengan adanya larangan anak bekerja karena bekerja adalah bagian dari hak asasi anak yang paling dasar. Meskipun masih anak-anak, hukum harus dapat menjamin terwujudnya hak anak yang paling asasi untuk mendapatkan pekerjaan dan oleh karenanya juga mendapatkan penghidupan yang layak bagi kemanusiaan. Masa depan anak tidak lagi ditentukan oleh kekuatan orang tua, keluarga, masyarakat, apalagi Negara. Tetapi sebaliknya orang tua, keluarga, masyarakat dan Negara, mempunyai kewajiban untuk menjamin terwujudnya hak anak yang paling asasi yakni mendapatkan pekerjaan dan penghidupan yang layak bagi kemanusiaan. Dalam hukum positif yang berlaku di Indonesia ini tidak dibenarkan ada peraturan perundangan yang mengeksploitasi sumber daya anak, hanya sekedar untuk kepentingan ekonomi, sosial, politik, budaya, hukum dalam perspektif orang tua, keluarga, masysrakat dan Negara.

2. Perlindungan hak-hak bagi pekerja anak sudah cukup memadai, meskipun belum adanya payung hukum yang secara khusus mengatur mengenai masalah pekerja anak dalam sebuah pengaturan perundang-undangan secara tersendiri, akan tetapi adanya pengaturan dalam Undang-Undang tentang Anak yang mengacu pada Konvensi Anak Internasional sudah menunjukkan upaya positif dari pemerintah untuk memberikan perlindungan hukum terhadap anak-anak.

\section{DAFTAR PUSTAKA}

\section{Buku}

Affandi, Idrus, 2007, Pendidikan Anak Berkonflik Hukum (model Konferensi Antara Fungsional dan Religious), Bandung, Afabeta.

Barda, Nawawi Arief. 1992. Perlindungan Anak menurut Negara Hukum. Jakarta: Penerbit Sinar Grafika.

Dian Ibung, 2009, Nilai-Nilai Moral Pada Anak, Jakarta, PT.Alex Media Komputindo.

Hardius Usman \& Djalal Nachrowi, 2004, Pekerja Anak di Indonesia : Kondisi, Determinan, dan Eksploitasi (Kajian Kuantitatif), Jakarta, Grasindo.

Indrasari dan B White. 1992. Anak-anak Desa dalam Kerja Upahan, Jakarta: Prisma. XXXI.

Syamsuddin. 1997. Petunjuk Pelaksanaan Penanganan Anakyang Bekerja. Jakarta: Penerbit Departemen Tenaga Kerja Republik Indonesia. 


\section{Peraturan Perundang-Undangan}

Kitab Undang-Undang Hukum Perdata

Undang-undang Nomor 20 Tahun 1999 Tentang Ratifikasi ILO Convention No. 138 Concerning Minimum Age for Admission to Employment the Abolition of Forced Labour, Lembaran Negara Republik Indonesia Tahun 1999 Nomor 56, Tambahan Lembaran Negara Republik Indonesia Nomor 3835.

Undang-undang Nomor 1 Tahun 2000 tentang Ratifikasi ILO Convention No. 182 Concerning the Prohibition anil Intermediate Action for the Elimination of The Worst Forms of Child Labour, Lembaran Negara Republik Indonesia Tahun 2000 Nomor 30, Tambahan Lembaran Negara Republik Indonesia Nomor 3941.

Undang-Undang No.13 Tahun 2003 Tentang Ketenagakerjaan, Lembaran Negara Republik Indonesia Tahun 2003 Nomor 39, Tambahan Lembaran Negara Republik Indonesia Nomor 4279.

Undang-Undang No.35 Tahun 2014 Tentang Perlindungan Anak, Lembaran Negara Republik Indonesia Tahun 2014 Nomor 279, Tambahan Lembaran Negara Republik Indonesia Nomor 5606. 